\title{
Dietary Dihydroartemisinin Supplementation Alleviates Intestinal Inflammatory Injury Through TLR4/NODs/NF-kB Signaling Pathway in Weaned Piglets with Intrauterine Growth Retardation
}

\section{Yu Niu}

Nanjing Agricultural University - Weigang Campus: Nanjing Agricultural University

Yongwei Zhao

Nanjing Agricultural University - Weigang Campus: Nanjing Agricultural University

Jintian He

Nanjing Agricultural University

Yang Yun

Nanjing Agricultural University

Mingming Shen

Nanjing Agricultural University

Zhending Gan

Nanjing Agricultural University

Lili Zhang

Nanjing Agricultural University

Tian Wang ( $\square$ tianwangnjau@163.com )

Nanjing Agricultural University

\section{Research}

Keywords: Intrauterine growth retardation, Weaned piglets, Dihydroartemisinin, Intestine injury, Inflammation, Morphology

Posted Date: October 2nd, 2020

DOI: https://doi.org/10.21203/rs.3.rs-84327/v1

License: (c) (1) This work is licensed under a Creative Commons Attribution 4.0 International License. Read Full License 
Version of Record: A version of this preprint was published at Animal Nutrition on May 1st, 2021. See the published version at https://doi.org/10.1016/j.aninu.2020.12.009. 


\section{Abstract}

Background: Intrauterine growth retardation (IUGR) leads to impaired intestinal morphology and function. IUGR infants are at a risk for intestinal inflammatory diseases. Dihydroartemisinin (DHA) is a derivative of artemisinin, which possesses anti-inflammatory activity and immunomodulatory effect. However, little is known about the effects of DHA on IUGR piglets. Therefore, the present study was conducted to investigate whether dietary DHA supplementation could attenuate intestinal injury in IUGR weaned piglets.

Methods: Piglets with normal birth weight or IUGR were fed the basal diet or basal diet supplemented with $80 \mathrm{mg} / \mathrm{kg}$ DHA from $21 \mathrm{~d}$ to 49 days of age. At 49 days of age, eight piglets from each group with nearly similar body weight were sacrificed. The jejunal and ileal samples were collected for further analysis.

Results: IUGR impaired intestinal morphology, increased intestinal inflammatory response, raised enterocyte apoptosis and reduced enterocyte proliferation and activated TLR4/NODs/NF-KB signaling pathway. DHA supplementation improved intestinal morphology, indicated by higher villus height, villus height to crypt depth ratio, villus surface area and lower villus width of IUGR piglets $(P<0.05)$. DHA inclusion exhibited higher apoptosis index and the expression of caspase-3, and lower proliferation index and the expression of proliferating cell nuclear antigen in the intestine of IUGR piglets $(P<0.05)$. Diet supplemented with DHA could attenuate intesitnal inflammation, indicated by higher concentrations of intestinal inflammatory cytokines and lipopolysaccharides in IUGR piglets $(P<0.05)$. In addition, DHA down-regulated the related mRNA expressions of TLR4/NODs/NF-KB signaling pathway and up-regulated mRNA expressions of TLR4 and NODs signaling negative regulators in the intestine of IUGR piglets $(P<$ 0.05). Dietary DHA supplementation decreased the protein expressions of toll-like receptors 4 , phosphorylated NF-kB (pNF-KB) inhibitor a, nuclear pNF-kB, and increased the protein expression of cytoplasmic pNF-KB in the intestine of IUGR piglets $(P<0.05)$.

Conclusions: Dietary DHA supplementation may have beneficial effects in improving intestinal morphology, regulating enterocyte proliferation and apoptosis, and alleviating intestinal inflammation through TLR4/NODs/NF-KB signaling pathway in IUGR weaned piglets.

\section{Background}

Intrauterine growth retardation (IUGR) is a common syndrome in the perinatal period, which can be defined as impaired growth and development of the mammalian embryo/fetus or its organs during pregnancy [1]. Researches have suggested that approximately $5-10 \%$ of human newborns suffer from IUGR [2]. Pigs, as multi-fetal animals, exhibit high incidence of IUGR (15\%-20\%), which have been used as a model for human IUGR studies [3]. IUGR leads to increased risk for neonatal and long-term morbidities affecting multiple organ systems including the intestine [4,5]. Infants with IUGR often display impaired intestinal morphology and function [4]. Study also demonstrated that infant with IUGR were at a risk for intestinal inflammatory diseases [6]. 
Dihydroartemisinin (DHA) is a kind of derivative of artemisinin, which is extracted from the traditional Chinese herb Artemisia annua L. [7]. DHA is mainly used to treat malaria for decades. Besides antimalaria activity, DHA also possesses anti-inflammatory activity and immunomodulatory effect [8]. An increasing number of studies have shown that DHA attenuates inflammatory injury through suppressing the activation of nuclear factor-KB (NF-KB) pathway [9-11]. Transmembrane toll like receptors (TLRs) and nucleotide binding and oligomerization domain (NOD)-like receptors (NLRs) are the key protein families of pattern recognition receptors, which are involved in mediating inflammatory process and expressed in many tissues including the intestine [12]. TLR4 is a significant member of TLRs, which plays an important role in innate immunity and inflammation by sensing pathogen-associated molecular patterns, such as lipopolysaccharide (LPS) [13]. When stimulated by LPS, TLR4 with the accessory proteins causes the activation of NF-KB via a series of signaling cascade reactions [14]. NOD1 and NOD2 are the better-characterized members of NLRs, which can also activate NF-KB [15]. NF-KB is a key transcription factor which regulates a large array of genes involved in the process of immune, inflammation and cell proliferation [16]. The activation of NF-KB modulates downstream targets and stimulates the production of pro-inflammatory cytokines IL-1 $\beta$, IL- 6 and TNF- $\alpha$, finally leading to tissue injury. However, no information is available about the effect and mechanism of DHA on intestinal inflammatory injury in IUGR piglets.

Accordingly, we hypothesized that (1) IUGR impaired intestinal integrity and increased intestinal inflammation of piglets; (2) dietary supplementation of DHA could improve intestinal integrity and reduce intestinal inflammation of IUGR piglets via TLR4/NODs/NF-KB signaling pathway. Therefore, the aim of this study is to investigate whether DHA could alleviate IUGR-induced intestinal injury in weaned pigletsand to elaborate its mechanisms. This research also provides a reference for treatment of IUGR in humans.

\section{Methods}

\section{Preparation of DHA}

The DHA used in this experiment was purchased from DASF Biotechnology Co., Ltd (Nanjing, Jiangsu, China). The content of DHA was up to $99 \%$ as determined by High Performance Liquid Chromatography analysis.

\section{Animals and experimental design}

All experimental design and procedures were approved by Institutional Animal Care and Use Committee of Nanjing Agricultural University following the requirements of the Regulations for the Administration of Affairs Concerning Experimental Animals of China (NJAU-CAST -2018-146). A total of twelve sows with similar birth order (third or fourth) were fed the same gestating diets that met the nutrient requirements of pregnant sows according to NRC (2012). At 114 days (SD 1) of gestation, the birth weight of each 
neonatal piglet [Duroc $\times($ Landrace $\times$ Yorkshire)] was recorded. Neonatal piglets with a birth weight (BW) close to the average BW of the total population (within 0.5 SD) were defined as normal birth weight (NBW), and those with a 2 SD lower BW were identified as IUGR $[17,18]$. From each litter, one NBW piglet $(1.56 \pm 0.02 \mathrm{~kg})$ and two IUGR piglets $(0.99 \pm 0.03 \mathrm{~kg})$ were selected and marked. All the newborn piglets were suckled with their own sows until weaning at 21 days of age. In each litter, the NBW piglet and one of the IUGR piglets were divided into two groups fed the basal diet (NBW-CON and IUGR-CON group, respectively). The other IUGR piglet was assigned to the group fed the basal diet supplemented with 80 $\mathrm{mg} / \mathrm{kg}$ DHA (IUGR-DHA group). The chemical composition of the diet was presented in Table 1, which was formulated to meet the nutrient requirements of piglets according to the NRC (2012). Piglets were housed individually in plastic floored pens $(1 \mathrm{~m} \times 0.6 \mathrm{~m})$ at an ambient temperature of 25 to $28^{\circ} \mathrm{C}$ and given ad libitum access to feed and water throughout the whole experimental period. 
Table 1

Composition and nutrient level of the basal diet (air-dry basis)

\begin{tabular}{|c|c|c|c|}
\hline Ingredients & Ratio (\%) & Calculated nutrient levels & Content \\
\hline Corn & 57.70 & Digestible energy (MJ/kg) & 14.04 \\
\hline Soybean meal (46\%) & 12.50 & Crude protein (\%) & 18.31 \\
\hline Expanded corn & 8.00 & Lysine (\%) & 1.31 \\
\hline Full-fat soybean & 8.00 & Methionine (\%) & 0.40 \\
\hline Fermented soybean meal & 4.00 & Methionine + Cystine (\%) & 0.70 \\
\hline Whey powder & 3.00 & Threonine (\%) & 0.80 \\
\hline Fish meal (crude protein 67\%) & 3.00 & Calcium (\%) & 0.85 \\
\hline Dicalcium phosphate & 1.80 & Total phosphorus (\%) & 0.72 \\
\hline Limestone & 0.50 & & \\
\hline L-lysine (78\%) & 0.30 & & \\
\hline L-threonine & 0.10 & & \\
\hline DL-methionine & 0.08 & & \\
\hline Wheat middling & 0.02 & & \\
\hline Premix $^{1}$ & 1 & & \\
\hline Total & 100 & & \\
\hline \multicolumn{4}{|c|}{$\begin{array}{l}{ }^{1} \text { The premix provided the following per kg complete diet: vitamin } \mathrm{A}, 12000 \mathrm{IU} \text {; vitamin } \mathrm{D}_{3}, 3000 \mathrm{IU} \text {; } \mathrm{a}- \\
\text { tocopherol, } 50 \mathrm{mg} \text {; vitamin } \mathrm{K}_{3}, 4 \mathrm{mg} \text {; vitamin } \mathrm{B}_{1}, 4 \mathrm{mg} \text {; vitamin } \mathrm{B}_{2}, 10 \mathrm{mg} \text {; vitamin } \mathrm{B}_{6}, 7 \mathrm{mg} \text {; vitamin } \\
\mathrm{B}_{12}, 0.05 \mathrm{mg} \text {; niacin, } 30 \mathrm{mg} \text {; pantothenic acid, } 15 \mathrm{mg} \text {; folic acid, } 0.3 \mathrm{mg} \text {; biotin, } 0.08 \mathrm{mg} \text {; choline } \\
\text { chloride, } 500 \mathrm{mg} ; \mathrm{Fe}\left(\mathrm{FeSO}_{4} \cdot \mathrm{H}_{2} \mathrm{O}\right), 110 \mathrm{mg} ; \mathrm{Cu}\left(\mathrm{CuSO}_{4} \cdot 5 \mathrm{H}_{2} \mathrm{O}\right), 7 \mathrm{mg} ; \mathrm{Zn}(\mathrm{ZnO}), 110 \mathrm{mg} \text { I ( }\left(\mathrm{KIO}_{3}\right), 0.3 \\
\mathrm{mg} ; \mathrm{Mn}\left(\mathrm{MnSO}_{4} \cdot \mathrm{H}_{2} \mathrm{O}\right), 5 \mathrm{mg} ; \mathrm{Se}\left(\mathrm{Na}_{2} \mathrm{SeO}_{3}\right), 0.3 \mathrm{mg} \text {. }\end{array}$} \\
\hline
\end{tabular}

\section{Sample collection}

At 49 days of age, eight piglets from each group with nearly similar body weight ( $n=8$, four barrows and four gilts) were sacrificed by intramuscular injection of sodium pentobarbital ( $50 \mathrm{mg} / \mathrm{kg} \mathrm{BW}$ ). Blood sample was collected from jugular vein puncture in a nonheparinized tube. The serum was separated by centrifugation for $15 \mathrm{~min}$ at $3000 \times \mathrm{g}$ at $4^{\circ} \mathrm{C}$ and stored at $-80^{\circ} \mathrm{C}$ until analysis. The small intestine without mesentery was removed from the abdominal cavity and divided into three segments: duodenum, jejunum and ileum according to previous study [19]. Segments measuring approximately $1 \mathrm{~cm}$ from the jejunum and ileum were collected and flushed gently with ice-cold phosphate-buffered saline (PBS, $\mathrm{pH}=$ 
7.4). Then the samples were fixed in $4 \%$ fresh, cold paraformaldehyde solution for histological analysis. In addition, jejunal and ileal segments measuring about $20 \mathrm{~cm}$ were opened longitudinally and flushed gently with ice-cold PBS ( $\mathrm{pH}=7.4)$. The mucosa was scraped from luminal surface using a sterile glass microscope slide and stored at $-80^{\circ} \mathrm{C}$ until analysis.

\section{Intestinal morphology analysis}

After fixation for $24 \mathrm{~h}$, the jejunal and ileal samples were dehydrated using a graded series of ethanol (70$100 \%$ ), cleared by xylene, and embedded in paraffin. Then the samples were cut at a thickness of $5 \mu \mathrm{m}$ and stained with hematoxylin and eosin. Six slices for each sample were prepared and the images of intestinal morphology were acquired using an optical binocular microscope with a digital camera (Nikon H5500L, Tokyo, Japan). Villus height (VH) and crypt depth (CD) were determined using Image-Pro Plus software. VH/CD was calculated by villus height to crypt depth ratio and villus area (VSA) was calculated using the following equation:

$$
\mathrm{VSA}=\pi \times \frac{\mathrm{Vw}}{2} \sqrt{\left(\frac{\mathrm{Vw}}{2}\right)^{2}+\mathrm{VH}^{2}}
$$

\section{Immunohistochemistry analysis}

Villus cell apoptosis was determined by terminal deoxynucleotidyl transferase (TdT)-mediated deoxyuridine triphosphate (dUTP) nick end labeling (TUNEL) staining method. Briefly, the slides were deparaffinised in xylene, dehydrated with alcohol, and pretreated with protease $\mathrm{K}$ for antigen retrieval. Then the sections were incubated with TdT and dUTP ( $\mathrm{vol}: \mathrm{vol}=1: 9$ ) according to the TUNEL kit (Roche Corporation, Basel, Switzerland). After washing with PBS ( $\mathrm{pH}=7.4)$, the slides were stained with DAPI dye and finally mounted with anti-fluorescein reagent. For each slide, the number of positive cells (stained cells) was counted from ten villi using a Nikon morphometric system (Nikon Corporation, Tokyo, Japan). Apoptosis index (Al) was defined as the ratio of the number of apoptotic TUNEL positive cells to total cell numbers multiplied by 100 .

$\mathrm{Ki}-67$ is a biomarker for proliferative activity and crypt cell proliferation is measured using Ki-67 immunohistochemistry staining [20]. Samples for intestinal morphology determination were used for immunohistochemistry analysis. The jejunal and ileal slices ( $5 \mu \mathrm{m}$ thick) were deparaffinised in xylene, dehydrated with alcohol, and microwave-pretreated in $10 \mathrm{mM}$ citrate buffer $(\mathrm{pH}=6.0)$ for antigen retrieval. After washing with PBS $(\mathrm{pH}=7.4)$, the tissue slices were incubated with $3 \% \mathrm{H}_{2} \mathrm{O}_{2}$ in dark for 25 min to eliminate the interference of endogenous peroxidase and then blocked with normal goat serum for 30 min to inhibit the non-specific interactions of the tissue with the primary antibody. Then the slides were incubated with the primary antibody (rabbit polyclonal to Ki67, Abcam, Cambridge, UK; 1:500) for 2 h and with secondary antibody (goat anti-rabbit IgG, Abcam, Cambridge, UK; 1:1000) conjugated with horseradish peroxidase for 50 min at room temperature. After washing with PBS ( $\mathrm{pH}=7.4)$, the sections 
were stained with diaminobenzidine (DAB) dye under the microscope to control the color-development time and then counterstained with hematoxylin for 3 min. Finally, the slides were dehydrated with ethanol and mounted with neutral balsam. For each slide, the number of positive cells (stained cells) was counted from ten crypts using a Nikon morphometric system (Nikon Corporation, Tokyo, Japan). The proliferation index $(\mathrm{PI})$ was defined as the ratio of the number of Ki-67 positive cells to total cell numbers multiplied by 100.

\section{Concentration of intestinal inflammatory cytokine analysis}

The systemic inflammatory biomarkers can be evaluated by intestinal pro-inflammatory cytokines including interleukin $1 \beta$ (IL-1 $\beta$ ), interleukin 6 (IL-6) and tumor necrosis factor a (TNF-a). The concentrations of IL-1 $\beta$, IL- 6 and TNF- $\alpha$ in the jejunum and ileum were measured by ELISA method using each antibody and biotinylated secondary antibody according to the instruction of manufacturer (YILI Biological Technology Co., Ltd, Shanghai, China).

\section{Concentration of intestinal lipopolysaccharide analysis}

The concentrations of lipopolysaccharide (LPS) in the jejunum and ileum were determined by ELISA methods using each antibody and biotinylated secondary antibody according to the instruction of manufacturer (YILI Biological Technology Co., Ltd, Shanghai, China).

\section{Gene expression analysis}

Total RNA was isolated from the frozen jejunal and ileal mucosa by using Trizol reagent (TaKaRa Biotechnology Co. Ltd, Dalian, Liaoning, China). The concentration of RNA was determined by using a spectrophotometer (NanoDrop 2000c, Thermo Scientific, Waltham, MA, USA) based on the absorption value at $260 \mathrm{~nm}$ or $280 \mathrm{~nm}$. The quality of RNA was accessed by agarose gel electrophoresis. Then the 1 $\mu \mathrm{g}$ of total RNA was reverse-transcribed into CDNA using the Perfect Real Time SYBR Premix Ex Taq kit (TaKaRa Biotechnology Co. Ltd, Dalian, China) according to the manufacturer's instructions. After that, quantitative real-time polymerase chain reaction (qRT-PCR) assays were conducted on an $A B I$ StepOnePlus Real-Time PCR detection system (Applied Biosystems; Carlsbad, CA, USA) by using a SYBR Premix Ex Taq Kit (TakaRa Biotechnology Co. Ltd; Dalian, Liaoning, China). The primer sequences for the target and reference genes were presented in Table 2. In detail, the reaction system was $20 \mu \mathrm{L}$ in total, including $2 \mu \mathrm{L}$ of cDNA, $0.4 \mu \mathrm{L}$ of forward primers, $0.4 \mu \mathrm{L}$ of reverse primers, $0.4 \mu \mathrm{L}$ of ROX Reference Dye, $10 \mu \mathrm{L}$ of SYBR Premix Ex Taq and $6.8 \mu \mathrm{L}$ of double-distilled water (TaKaRa Biotechnology Co. Ltd., Dalian, Liaoning, China). The thermocycle used for qRT-PCR was $95^{\circ} \mathrm{C}$ for $30 \mathrm{~s}$ for one cycle, 40 cycles of $5 \mathrm{~s}$ at $95^{\circ} \mathrm{C}$, and $30 \mathrm{~s}$ at $60^{\circ} \mathrm{C}$. Each sample was run in duplicate. The mRNA expression level of each gene was calculated with $2^{-\Delta \Delta C t}$ method after normalization with the housekeeper gene $\beta$-actin. 
Table 2

Primer sequences of target genes

\begin{tabular}{|c|c|c|c|}
\hline Gene & Accession No. & Sequences & Product length (bp) \\
\hline \multirow[t]{2}{*}{$\beta$-actin } & XM_003124280.4 & F: CACGCCATCCTGCGTCTGGA & 380 \\
\hline & & R: AGCACCGTGTTGGCGTAGAG & \\
\hline \multirow[t]{2}{*}{ TLR4 } & GQ503242.1 & F: TCAGTTCTCАССTTССТССТG & 166 \\
\hline & & R: GTTCATTCCTCACCCAGTCTTC & \\
\hline \multirow[t]{2}{*}{ MyD88 } & AB292176.1 & F: GATGGTAGCGGTTGTCTCTGAT & 148 \\
\hline & & R: GATGCTGGGGAACTCTTTCTTC & \\
\hline \multirow[t]{2}{*}{ IRAK1 } & XM_003135490.1 & F: CAAGGCAGGTCAGGTTTCGT & 115 \\
\hline & & R: TTCGTGGGGCGTGTAGTGT & \\
\hline \multirow[t]{2}{*}{ TRAF6 } & NM_001105286.1 & F: CAAGAGAATACCCAGTCGCACA & 122 \\
\hline & & R: ATCCGAGACAAAGGGGAAGAA & \\
\hline \multirow[t]{2}{*}{ NOD1 } & AB187219.1 & F: CTGTCGTCAACACCGATCCA & 57 \\
\hline & & R: CCAGTTGGTGACGCAGCTT & \\
\hline \multirow[t]{2}{*}{ NOD2 } & AB195466.1 & F: GAGCGCATCCTCTTAACTTTCG & 66 \\
\hline & & R: ACGCTCGTGATCCGTGAAC & \\
\hline \multirow[t]{2}{*}{ RIPK2 } & XM_003355027.1 & F: CAGTGTCCAGTAAATCGCAGTTG & 206 \\
\hline & & R: CAGGCTTCCGTCATCTGGTT & \\
\hline \multirow[t]{2}{*}{ NF-KB p65 } & EU399817.1 & F: AGTACCCTGAGGCTATAACTCGC & 133 \\
\hline & & R: TCCGCAATGGAGGAGAAGTC & \\
\hline \multirow[t]{2}{*}{ RP105 } & AB190767.1 & F: CGAGGCTTCTGACTGTTGTG & 245 \\
\hline & & R: GGTGCTGATTGCTGGTGTC & \\
\hline \multirow[t]{2}{*}{ SOCS1 } & NM_001204768.1 & F: GCGTGTAGGATGGTAGCA & 101 \\
\hline & & R: GAGGAGGAGGAGGAGGAAT & \\
\hline \multirow[t]{2}{*}{ Tollip } & AB490123.1 & F: GCAGCAGCAACAGCAGAT & 133 \\
\hline & & R: GGTCACGCCGTAGTTCTTC & \\
\hline \multirow[t]{2}{*}{$E R B B 2 I P$} & GU990777.1 & F: ACAATTCAGCGACAGAGTAGTG & 147 \\
\hline & & R: TGACATCATTGGAGGAGTTCTTC & \\
\hline CENTB1 & XM_003358258.2 & F: GAAGCCGAAGTGTCCGAATT & 125 \\
\hline
\end{tabular}


$T L R 4$, toll-like receptor 4; MyD88, myeloid differentiation factor 88; IRAK1, IL-1 receptor-associated kinase 1; TRAF6, TNF receptor-associated factor $6 . N O D$, nucleotide-binding oligomerization domain protein; $R I P K 2$, receptor-interacting serine/threonine-protein kinase 2; $N F-K B$ p65, nuclear factor-kB p65; RP105, radioprotective 105; SOCS1, suppressor of cytokine signaling 1; Tollip, toll-interacting protein; ERBB2IP, Erbb2 interacting protein; CENTB1, centaurin $\beta 1$.

\section{Western blot analysis}

Antibodies against caspase-3 (1:500), proliferating cell nuclear antigen (PCNA, 1:500), toll-like receptors 4 (TLR4, 1:500) were purchased from Abcam plc. (Cambridge, UK). Antibodies against myeloid differentiation factor 88 (MyD88, 1:1000), total nuclear factor KB (NF-кB, 1:1000), phosphorylated nuclear factor KB (pNF-кB, 1:1000), total NF-кB inhibitor a (tlкBa, 1:1000) and phosphorylated NF-kB inhibitor a (plкBa, 1:1000), $\beta$-actin (1:1000) and $\mathrm{Na}$, K-ATPase (1:1000) were purchased from Cell Signaling Technology, Inc. (Danvers, MA, USA). The total, nuclear or cytoplasmic proteins of intestinal mucosal samples were extracted using assay kits according to the manufacturer's instructions (Beyotime Institute of Biotechnology, Haimen, Jiangsu, China). The protein concentration of each sample was measured using the BCA Protein Assay Kit (Nanjing Jiancheng Bioengineering Institute, Nanjing, Jiangsu, China). For western blot analysis, $60 \mu \mathrm{g}$ protein from each sample was electrophoresed in sodium dodecyl sulfate-polyacrylamide gels and then transferred to polyvinylidene difuoride membranes. After blocking in Tris-Tween buffered saline (TBST; 0.1\% Tween-20, $100 \mathrm{mmol} / \mathrm{L}$ Tris- $\mathrm{HCl}$, and $150 \mathrm{mmol} / \mathrm{L} \mathrm{NaCl}, \mathrm{pH}=8.0$ ) containing $5 \%$ non-fat dry milk for $2 \mathrm{~h}$ at room temperature, the membranes were washed in TBST for three times and incubated with primary antibodies overnight at $4^{\circ} \mathrm{C}$ with gentle rocking. Then the membranes were washed for three times again and incubated with secondary antibodies (goat anti-rabbit IgG or goat anti-mouse IgG, 1:2000; Abcam, Cambridge, UK) at room temperature for 60 min. The blots were detected using enhanced chemiluminescence reagents (Beyotime Institute of Biotechnology, Haimen, Jiangsu, China) followed by autoradiography. Images of the membranes were snapped with a Luminescent Image Analyzer LAS-4000 system (Fujifilm Co. Ltd., Tokyo, Japan) and quantified by the Gel-Pro Analyzer 4.0 software (Media Cybernetics, Silver Spring, MD, USA).

\section{Statistical analysis}

Data were analyzed using SPSS statistical software (Ver. 20.0 for windows, SPSS, Chicago, IL, USA). Statistical differences among treatment groups were determined by one-way analysis of variance (ANOVA) and Tukey's post hoc test was used for multiple comparisons. A probably level of $P<0.05$ was considered as statistically significant. Values were presented as means \pm SEM.

\section{Results}




\section{Intestinal morphology}

IUGR decreased $(P<0.05) \mathrm{VH}, \mathrm{VCR}$ and VSA and increased $(P<0.05) \mathrm{CD}$ in both jejunum and ileum of piglets (Table 3). DHA administration effectively exhibited an increased $(P<0.05) \mathrm{VH}, \mathrm{VCR}$ and VSA and a decreased $(P<0.05)$ CD in the intestine of IUGR piglets.

Table 3

Effect of dietary dihydroartemisinin supplementation on intestinal morphology in weaned piglets with intrauterine growth retardation.

\begin{tabular}{|c|c|c|c|c|c|}
\hline \multirow[t]{3}{*}{ Items } & \multicolumn{3}{|l|}{ Treatment $^{1}$} & \multicolumn{2}{|l|}{$P$ value $^{2}$} \\
\hline & NBW-CON & IUGR-CON & IUGR-DHA & NC vs. IC & IC vs. ID \\
\hline & (NC) & (IC) & (ID) & & \\
\hline \multicolumn{6}{|l|}{ Jejunum } \\
\hline $\mathrm{VH}(\mu \mathrm{m})$ & $466.35 \pm 7.16$ & $366.91 \pm 4.06^{*}$ & $446.11 \pm 5.21 \#$ & $<0.001$ & $<0.001$ \\
\hline $\mathrm{VW}(\mu \mathrm{m})$ & $88.40 \pm 1.01$ & $85.68 \pm 0.95$ & $85.71 \pm 0.96$ & 0.146 & 1.000 \\
\hline $\mathrm{CD}(\mu \mathrm{m})$ & $170.52 \pm 2.51$ & $233.07 \pm 2.85^{\star}$ & $206.48 \pm 2.38^{\#}$ & $<0.001$ & $<0.001$ \\
\hline VCR & $2.74 \pm 0.05$ & $1.58 \pm 0.02^{*}$ & $2.16 \pm 0.02^{\#}$ & $<0.001$ & $<0.001$ \\
\hline VSA $\left(\mathrm{mm}^{2}\right)$ & $0.065 \pm 0.002$ & $0.050 \pm 0.001^{*}$ & $0.060 \pm 0.001^{\#}$ & $<0.001$ & $<0.001$ \\
\hline \multicolumn{6}{|l|}{ Ileum } \\
\hline $\mathrm{VH}(\mu \mathrm{m})$ & $369.16 \pm 5.92$ & $321.63 \pm 2.37^{*}$ & $360.97 \pm 4.63^{\#}$ & $<0.001$ & $<0.001$ \\
\hline $\mathrm{VW}(\mu \mathrm{m})$ & $88.70 \pm 1.54$ & $85.11 \pm 1.18$ & $85.81 \pm 1.12$ & 0.147 & 0.922 \\
\hline $\mathrm{CD}(\mu \mathrm{m})$ & $156.05 \pm 4.22$ & $236.96 \pm 4.89^{*}$ & $206.26 \pm 3.10^{\#}$ & $<0.001$ & $<0.001$ \\
\hline VCR & $2.37 \pm 0.05$ & $1.36 \pm 0.03^{*}$ & $1.75 \pm 0.03^{\#}$ & $<0.001$ & $<0.001$ \\
\hline $\operatorname{VSA}\left(\mathrm{mm}^{2}\right)$ & $0.052 \pm 0.001$ & $0.043 \pm 0.001^{*}$ & $0.049 \pm 0.001^{\#}$ & $<0.001$ & 0.001 \\
\hline \multicolumn{6}{|c|}{$\begin{array}{l}{ }^{1} \mathrm{NBW}-\mathrm{CON}(\mathrm{NC}) \text { group, normal body weight weaned piglets fed with basal diet; IUGR-CON (IC) group, } \\
\text { intrauterine growth retardation weaned piglets fed with basal diet; IUGR-DHA (ID) group, intrauterine } \\
\text { growth retardation weaned piglets fed with } 80 \mathrm{mg} / \mathrm{kg} \text { dihydroartemisinin. Data were presented as } \\
\text { mean } \pm \text { SEM }(\mathrm{n}=8) .{ }^{2} \mathrm{~A} \text { value of }{ }^{*} P<0.05 \text { was considered as statistically significant difference when } \\
\text { compared with NBW-CON group; }{ }^{*} P<0.05 \text { was considered as statistically significant difference when } \\
\text { compared with IUGR-CON group. VH, villus height; VD, villus width; CD, crypt depth; VCR, villus height } \\
\text { to crypt depth ratio; VSA, villus surface area. }\end{array}$} \\
\hline
\end{tabular}




\section{Cell apoptosis and proliferation}

IUGR piglets showed higher $(P<0.05) \mathrm{Al}($ Fig. 1$)$ and lower $(P<0.05) \mathrm{PI}($ Fig. 2$)$ in both jejunum and ileum than NBW piglets (Table 4). The level of caspase-3 is the marker of cell apoptosis and PCNA is the marker of cell proliferation. The results showed that IUGR decreased $(P<0.05)$ the protein expression of caspase3 (Fig. 3) and increased $(P<0.05)$ the protein expression of PCNA (Fig. 4$)$ in jejunum and ileum of piglets. Diet supplemented with DHA effectively enhanced $(P<0.05) \mathrm{PI}$ and level of PCNA, and reduced $(P<0.05)$ Al and level of caspase-3 in both jejunum and ileum of IUGR piglets.

Table 4

Effect of dietary dihydroartemisinin supplementation on enterocyte proliferation and apoptosis in weaned piglets with intrauterine growth retardation.

\begin{tabular}{|c|c|c|c|c|c|}
\hline \multirow[t]{3}{*}{ Items } & \multicolumn{3}{|l|}{ Treatment $^{1}$} & \multicolumn{2}{|l|}{$P$ value $^{2}$} \\
\hline & NBW-CON & IUGR-CON & IUGR-DHA & NC vs. IC & IC vs. ID \\
\hline & (NC) & (IC) & (ID) & & \\
\hline \multicolumn{6}{|c|}{ Jejunum } \\
\hline $\mathrm{Al}(\%)$ & $3.80 \pm 0.25$ & $9.72 \pm 0.42^{*}$ & $6.62 \pm 0.15^{\#}$ & $<0.001$ & $<0.001$ \\
\hline PI (\%) & $21.44 \pm 1.22$ & $15.07 \pm 0.60^{\star}$ & $20.08 \pm 0.89^{\#}$ & 0.001 & 0.005 \\
\hline \multicolumn{6}{|l|}{ Ileum } \\
\hline $\mathrm{Al}(\%)$ & $4.05 \pm 0.24$ & $7.13 \pm 0.25^{*}$ & $5.31 \pm 0.30^{\#}$ & $<0.001$ & 0.001 \\
\hline PI (\%) & $30.10 \pm 1.11$ & $18.18 \pm 1.03^{*}$ & $28.42 \pm 1.41^{\#}$ & $<0.001$ & $<0.001$ \\
\hline \multicolumn{6}{|c|}{$\begin{array}{l}{ }^{1} \mathrm{NBW}-\mathrm{CON}(\mathrm{NC}) \text { group, normal body weight weaned piglets fed with basal diet; IUGR-CON (IC) group, } \\
\text { intrauterine growth retardation weaned piglets fed with basal diet; IUGR-DHA (ID) group, intrauterine } \\
\text { growth retardation weaned piglets fed with } 80 \mathrm{mg} / \mathrm{kg} \text { dihydroartemisinin. Data were presented as } \\
\text { mean } \pm \text { SEM }(\mathrm{n}=8) .{ }^{2} \mathrm{~A} \text { value of }{ }^{*} P<0.05 \text { was considered as statistically significant difference when } \\
\text { compared with NBW-CON group; }{ }^{\#} P<0.05 \text { was considered as statistically significant difference when } \\
\text { compared with IUGR-CON group. Al, apoptosis index; PI, proliferation index. }\end{array}$} \\
\hline
\end{tabular}

\section{Concentrations of intestinal inflammatory cytokines}

In the jejunum, the concentrations of inflammatory cytokines IL-1 $\beta$, IL- 6 and TNF-a were increased $(P<$ 0.05 ) in the IUGR-CON group compared with the NBW-CON group (Table 5). IUGR piglets fed the DHA diet significantly decreased $(P<0.05)$ the concentrations of IL-1 $\beta$ and IL- 6 compared with those fed the basal diet. In the ileum, the concentrations of IL-1 $\beta$ and IL- 6 in the IUGR-CON group were higher $(P<0.05)$ than 
those of NBW-CON group. After treatment with DHA, IUGR piglets decreased $(P<0.05)$ the concentrations of IL-1 $\beta$, IL-6 and TNF-a.

Table 5

Effect of dietary dihydroartemisinin supplementation on the concentrations of intestinal inflammatory cytokines in weaned piglets with intrauterine growth retardation.

\begin{tabular}{|c|c|c|c|c|c|}
\hline \multirow[t]{3}{*}{ Items } & \multicolumn{3}{|l|}{ Treatment $^{1}$} & \multicolumn{2}{|l|}{$P$ value $^{2}$} \\
\hline & NBW-CON & IUGR-CON & IUGR-DHA & NC vs. IC & IC vs. ID \\
\hline & (NC) & (IC) & (ID) & & \\
\hline \multicolumn{6}{|l|}{ Jejunum } \\
\hline IL-1 $\beta$ (ng/g protein) & $33.61 \pm 3.21$ & $54.08 \pm 3.00^{*}$ & $40.44 \pm 1.65^{\#}$ & $<0.001$ & 0.008 \\
\hline IL-6 (ng/g protein) & $64.73 \pm 3.40$ & $83.68 \pm 2.96^{*}$ & $62.67 \pm 3.63^{\#}$ & 0.005 & 0.002 \\
\hline TNF-a (ng/g protein) & $17.93 \pm 0.68$ & $22.13 \pm 1.13^{*}$ & $20.11 \pm 1.12$ & 0.024 & 0.350 \\
\hline \multicolumn{6}{|l|}{ Ileum } \\
\hline IL-1 $\beta$ (ng/g protein) & $26.68 \pm 1.86$ & $33.66 \pm 1.71^{*}$ & $26.59 \pm 1.71^{\#}$ & 0.037 & 0.032 \\
\hline IL-6 (ng/g protein) & $56.67 \pm 3.05$ & $72.24 \pm 2.55^{*}$ & $60.91 \pm 2.73^{\#}$ & 0.003 & 0.029 \\
\hline TNF-a (ng/g protein) & $15.13 \pm 1.29$ & $16.76 \pm 0.62$ & $13.14 \pm 0.63^{\#}$ & 0.433 & 0.032 \\
\hline \multicolumn{6}{|c|}{$\begin{array}{l}{ }^{1} \mathrm{NBW}-\mathrm{CON}(\mathrm{NC}) \text { group, normal body weight weaned piglets fed with basal diet; IUGR-CON (IC) group, } \\
\text { intrauterine growth retardation weaned piglets fed with basal diet; IUGR-DHA (ID) group, intrauterine } \\
\text { growth retardation weaned piglets fed with } 80 \mathrm{mg} / \mathrm{kg} \text { dihydroartemisinin. Data were presented as } \\
\text { mean } \pm \text { SEM }(\mathrm{n}=8) .{ }^{2} \mathrm{~A} \text { value of }{ }^{*} P<0.05 \text { was considered as statistically significant difference when } \\
\text { compared with NBW-CON group; }{ }^{\#} P<0.05 \text { was considered as statistically significant difference when } \\
\text { compared with IUGR-CON group. IL-1 } \beta \text {, interleukin } 1 \beta \text {; IL-6, interleukin } 6 \text {; TNF-a, tumor necrosis factor } \\
\text { a. }\end{array}$} \\
\hline
\end{tabular}

\section{Concentrations of intestinal LPS}

Piglets in the IUGR-CON group exhibited increased $(P<0.05)$ LPS concentration in comparison with those of NBW piglets in both jejunum and ileum (Fig. 5). Supplementation with DHA significantly reduced $(P<$ 0.05 ) the concentrations of LPS in the intestine of IUGR piglets.

\section{Intestinal mRNA expressions of TLR4/NODs/NF-kB signaling pathway}


As presented in Table 6, IUGR up-regulated $(P<0.05)$ the mRNA expressions of $T L R 4, M y D 88$, IRAK1, NOD1, RIPK2, and NF-KB p65 in the jejunum, and TLR4, NOD1, NOD2, RIPK2, and NF-KB p65 in the ileum of the IUGR-CON group in comparison with the NBW-CON group. Dietary DHA supplementation downregulated $(P<0.05)$ the mRNA expressions of jejunal TLR4, IRAK1, NOD1, RIPK2, and NF-KB p65 and ileal $T L R 4, N O D 1, N O D 2, R I P K 2$, and NF-KB p65 of IUGR piglets. 
Table 6

Effect of dietary dihydroartemisinin supplementation on intestinal mRNA abundance of TLR4/NODs/NFKB signaling pathway in weaned piglets with intrauterine growth retardation.

\begin{tabular}{|c|c|c|c|c|c|}
\hline \multirow[t]{3}{*}{ Items } & \multicolumn{3}{|l|}{ Treatment $^{1}$} & \multicolumn{2}{|l|}{$P$ value ${ }^{2}$} \\
\hline & NBW-CON & IUGR-CON & IUGR-DHA & NC vs. IC & IC vs. ID \\
\hline & (NC) & (IC) & (ID) & & \\
\hline \multicolumn{6}{|l|}{ Jejunum } \\
\hline$T L R 4$ & $1.00 \pm 0.05$ & $1.41 \pm 0.06^{*}$ & $0.64 \pm 0.04^{\#}$ & $<0.001$ & $<0.001$ \\
\hline MyD88 & $1.00 \pm 0.04$ & $1.36 \pm 0.05^{*}$ & $1.20 \pm 0.05$ & $<0.001$ & 0.076 \\
\hline IRAK1 & $1.00 \pm 0.12$ & $2.08 \pm 0.08^{\star}$ & $0.44 \pm 0.07^{\#}$ & $<0.001$ & $<0.001$ \\
\hline TRAF6 & $1.00 \pm 0.05$ & $0.87 \pm 0.07$ & $0.91 \pm 0.05$ & 0.272 & 0.883 \\
\hline NOD1 & $1.00 \pm 0.07$ & $1.55 \pm 0.10^{\star}$ & $1.03 \pm 0.04^{\#}$ & $<0.001$ & $<0.001$ \\
\hline NOD2 & $1.00 \pm 0.06$ & $0.92 \pm 0.09$ & $0.83 \pm 0.06$ & 0.690 & $0 . .636$ \\
\hline RIPK2 & $1.00 \pm 0.10$ & $1.58 \pm 0.11^{*}$ & $0.97 \pm 0.04^{\#}$ & 0.001 & 0.001 \\
\hline NF-KB p65 & $1.00 \pm 0.09$ & $1.75 \pm 0.15^{\star}$ & $0.76 \pm 0.07^{\#}$ & 0.001 & $<0.001$ \\
\hline \multicolumn{6}{|l|}{ Ileum } \\
\hline$T L R 4$ & $1.00 \pm 0.16$ & $2.89 \pm 0.19^{*}$ & $1.87 \pm 0.15^{\#}$ & $<0.001$ & 0.002 \\
\hline MyD88 & $1.00 \pm 0.12$ & $0.97 \pm 0.17$ & $0.84 \pm 0.18$ & 0.993 & 0.823 \\
\hline IRAK1 & $1.00 \pm 0.08$ & $1.08 \pm 0.07$ & $0.72 \pm 0.10$ & 0.799 & 0.021 \\
\hline TRAF6 & $1.00 \pm 0.10$ & $0.71 \pm 0.12$ & $0.99 \pm 0.16$ & 0.280 & 0.299 \\
\hline NOD1 & $1.00 \pm 0.14$ & $1.99 \pm 0.14^{*}$ & $1.40 \pm 0.14^{\#}$ & $<0.001$ & 0.025 \\
\hline NOD2 & $1.00 \pm 0.07$ & $2.55 \pm 0.16^{*}$ & $0.66 \pm 0.09^{\#}$ & $<0.001$ & $<0.001$ \\
\hline RIPK2 & $1.00 \pm 0.15$ & $2.42 \pm 0.08^{*}$ & $1.17 \pm 0.18^{\#}$ & $<0.001$ & $<0.001$ \\
\hline NF-KB p65 & $1.00 \pm 0.11$ & $1.75 \pm 0.15^{\star}$ & $1.26 \pm 0.07^{\#}$ & 0.001 & 0.025 \\
\hline
\end{tabular}

${ }^{1}$ NBW-CON (NC) group, normal body weight weaned piglets fed with basal diet; IUGR-CON (IC) group, intrauterine growth retardation weaned piglets fed with basal diet; IUGR-DHA (ID) group, intrauterine growth retardation weaned piglets fed with $80 \mathrm{mg} / \mathrm{kg}$ dihydroartemisinin. Data were presented as mean \pm SEM $(n=8) .{ }^{2}$ A value of ${ }^{*} P<0.05$ was considered as statistically significant difference when compared with NBW-CON group; ${ }^{\#} P<0.05$ was considered as statistically significant difference when compared with IUGR-CON group. TLR4, toll-like receptor 4; MyD88, myeloid differentiation factor 88; IRAK1, IL-1 receptor-associated kinase 1; TRAF6, TNF receptor-associated factor 6 . NOD, nucleotide- 


\section{Intestinal protein expressions of TLR4/NODs/NF-kB signaling pathway}

As shown in Fig. 6, IUGR piglets exhibited higher $(P<0.05)$ protein expressions of TLR4, plkBa, nuclear pNF-kB and lower $(P<0.05)$ cytoplasmic pNF-KB levels in both jejunum and ileum than those of NBW piglets. DHA supplementation effectively improved $(P<0.05)$ the alternation of these protein expressions in IUGR piglets. The protein expression of MyD88 was also increased $(P<0.05)$ in the jejunum of IUGRCON group compared to that of NBW-CON group. However, feeding the IUGR piglets with DHA diet had no significant effect on the MyD88 levels $(P>0.05)$.

\section{Intestinal mRNA expressions of negative regulators of TLR4/NODs signaling pathway}

As shown in Table 7, the mRNA expressions of jejunal Tollip, ERBB2IP, and CENTB1 and ileal SOCS1, ERBB2IP and CENTB1 were reduced $(P<0.05)$ in the IUGR-CON group when compared with the NBW-CON group. Diet supplemented with DHA increased $(P<0.05)$ the mRNA expressions of these genes in both jejunum and ileum of IUGR piglets. 
Table 7

Effect of dietary dihydroartemisinin supplementation on intestinal mRNA abundance of negative regulators of TLR4/NODs signaling pathway in weaned piglets with intrauterine growth retardation.

\begin{tabular}{|c|c|c|c|c|c|}
\hline \multirow[t]{3}{*}{ Items } & \multicolumn{3}{|l|}{ Treatment $^{1}$} & \multicolumn{2}{|l|}{$P$ value $^{2}$} \\
\hline & NBW-CON & IUGR-CON & IUGR-DHA & NC vs. IC & IC vs. ID \\
\hline & (NC) & (IC) & (ID) & & \\
\hline \multicolumn{6}{|l|}{ Jejunum } \\
\hline RP105 & $1.00 \pm 0.09$ & $0.89 \pm 0.07$ & $0.86 \pm 0.07$ & 0.537 & 0.972 \\
\hline SOCS1 & $1.00 \pm 0.04$ & $1.02 \pm 0.14$ & $0.96 \pm 0.18$ & 0.991 & 0.955 \\
\hline Tollip & $1.00 \pm 0.05$ & $0.57 \pm 0.04^{\star}$ & $0.86 \pm 0.03^{\#}$ & $<0.001$ & $<0.001$ \\
\hline$E R B B 2 I P$ & $1.00 \pm 0.04$ & $0.22 \pm 0.03^{*}$ & $0.72 \pm 0.05^{\#}$ & $<0.001$ & $<0.001$ \\
\hline CENTB1 & $1.00 \pm 0.05$ & $0.56 \pm 0.07^{\star}$ & $1.13 \pm 0.08^{\#}$ & 0.001 & $<0.001$ \\
\hline \multicolumn{6}{|l|}{ Ileum } \\
\hline RP105 & $1.00 \pm 0.08$ & $1.05 \pm 013$ & $1.06 \pm 0.17$ & 0.969 & 0.998 \\
\hline SOCS1 & $1.00 \pm 0.11$ & $0.37 \pm 0.07^{\star}$ & $0.79 \pm 0.10^{\#}$ & 0.001 & 0.018 \\
\hline Tollip & $1.00 \pm 0.13$ & $0.74 \pm 0.13$ & $1.02 \pm 0.15$ & 0.398 & 0.356 \\
\hline ERBB2IP & $1.00 \pm 0.08$ & $0.28 \pm 0.04^{*}$ & $0.61 \pm 0.11^{\#}$ & $<0.001$ & 0.033 \\
\hline CENTB1 & $1.00 \pm 0.03$ & $0.31 \pm 0.05^{\star}$ & $0.82 \pm 0.05^{\#}$ & $<0.001$ & $<0.001$ \\
\hline \multicolumn{6}{|c|}{$\begin{array}{l}{ }^{1} \mathrm{NBW}-\mathrm{CON}(\mathrm{NC}) \text { group, normal body weight weaned piglets fed with basal diet; IUGR-CON (IC) group, } \\
\text { intrauterine growth retardation weaned piglets fed with basal diet; IUGR-DHA (ID) group, intrauterine } \\
\text { growth retardation weaned piglets fed with } 80 \mathrm{mg} / \mathrm{kg} \text { dihydroartemisinin. Data were presented as } \\
\text { mean } \pm \mathrm{SEM}(\mathrm{n}=8) .{ }^{2} \mathrm{~A} \text { value of }{ }^{*} P<0.05 \text { was considered as statistically significant difference when } \\
\text { compared with NBW-CON group; }{ }^{*} P<0.05 \text { was considered as statistically significant difference when } \\
\text { compared with IUGR-CON group. RP105, radioprotective } 105 \text {; SOCS1, suppressor of cytokine signaling } \\
\text { 1; Tollip, toll-interacting protein; ERBB2IP, Erbb2 interacting protein; CENTB1, centaurin } \beta 1 \text {. }\end{array}$} \\
\hline
\end{tabular}

\section{Discussion}

The intestine is the biggest immune organ involved in immune and inflammatory reaction. Intestinal integrity mainly depends on the intact intestinal morphology which reflects gut health in humans and animals. Intestinal morphology can be assessed by villus height, crypt depth, villus to crypt ratio and villus surface area [21, 22]. In the current study, VH, VCR and VSA were reduced and CD was increased in both jejunum and ileum of IUGR weaned piglets compared to the NBW weaned piglets, suggesting a 
decreased ability of intestinal absorption as well as an impaired intestinal integrity in IUGR piglets. These results were consistent with previous studies on IUGR piglets [3, 23-25]. Dietary supplementation with DHA enhanced VH, VCR, and VSA and decreased CD in IUGR piglets, indicating that DHA could improve the intestinal morphology.

Previous study demonstrated that the impaired intestinal morphology may be associated with the imbalance of cell apoptosis and proliferation [26]. In the current study, IUGR piglets enhanced the Al and reduced the PI of enterocytes when compared with NBW weaned piglets. Similar results were found in IUGR neonatal piglets [27]. The results also agreed with previous studies that IUGR increased cell apoptosis in the small intestine of rats[28] and decreased enterocyte proliferation in newborn rabbits [29]. However, the findings were dissimilar to previous study reported by Li et al. [26], who noted that IUGR increased the proportion of villus apoptosis cells and crypt proliferative cells in the ileum of IUGR weanling piglets. The reason may be attributed to a compensatory process in response to the excessive apoptosis in the villus. It is clear that caspase- 3 is a frequently activated protease in mammalian cell apoptosis [30]. PCNA is an intranuclear polypeptide whose expression and synthesis are evaluated as the marker of cell proliferation [31]. In the present study, IUGR enhanced the protein expression of caspase-3 and reduced the protein expression of PCNA in both jejunum and ileum of weaned piglets. Previous research suggested that the expression of caspase-3 was increased and the expression of PCNA was decreased in the placentas of IUGR rats [32]. The results were also similar to previous observations that the TUNEL staining and caspase-3 activity were increased in the kidney of IUGR rats [33]. After DHA treatment, the protein expression of caspase-3 was decreased and PCNA was increased in IUGR piglets. These results indicated that IUGR was linked with decreased cell proliferation and increased cell apoptosis in small intestine and DHA inclusion could improve the excessive apoptosis in IUGR weaned piglets.

It was reported that excessive intestinal epithelial cell apoptosis disrupted intestinal integrity and permitted the invasion of luminal antigens into the lamina propria, thereby leading to the inflammatory response and release of pro-inflammatory cytokines [34]. The present study showed that IUGR increased the concentrations of pro-inflammation cytokines IL-1 $\beta$, IL-6, TNF- $\alpha$ in the jejunum and IL-1 $\beta$, IL- 6 in the ileum of IUGR piglets. Consistent with previous study, Huang et al. [35] observed higher levels of TNF-a and IL-6 in IUGR piglets at birth, suggesting that IUGR newborns was prone to inflammatory injury. Diet supplemented with DHA decreased the concentrations of pro-inflammation cytokines. Previous study showed that DHA decreased the concentrations of IL- 6 and IL-1 $\beta$ induced by TNF- $\alpha$ in endothelial cells [7]. Research also demonstrated that DHA administration down-regulated the expressions of IL-1 $\beta$ and IL- 6 in LPS-induced mice [36]. The results indicated that DHA could attenuate the intestinal inflammatory response of IUGR piglets by reducing the levels of pro-inflammation cytokines due to its antiinflammatory activity.

In order to clearly illustrate the molecular mechanism of DHA supplementation on attenuating the intestinal inflammatory response, we determined the function of TLRs and NLRs [37], which also play important roles in the dysregulated apoptosis [38]. TLR4 is a best characterized member of TLRs, which 
is a signaling receptor for recognizing LPS [39]. LPS or endotoxin, the major component of outer membrane of Gram-negative bacteria, is a potent activator that elicits inflammatory responses in mammalian cells [40]. When the intestine is stimulated by LPS, TLR4/CD14/MD2 complex recruits and activates an adapter protein myeloid differentiation protein 88 (MyD88), which in turn recruits IL-1 receptor-associated kinase 1 (IRAK1) [41]. The receptor complex then interacts with the adapter molecule TNF receptor-associated factor 6 (TRAF6) $[42,43]$ and subsequently activates the NF-KB inhibitor (IKB) Ikinase complex (IKKa and IKKB) which directly phosphorylates IKB [44-46]. The phosphorylation of IKB family eventually activates nuclear factor-KB (NF-KB) and results in the subsequent translocation of NF$K B$ to the nucleus [47]. In addition, the intracellulars NLR proteins are also involved in the activation of NFKB pathway. Among NLRs, NOD1 and NOD2 recognize the dipeptideg-D-glutamyl-meso-diaminopimelic acid (iE-DAP) and muramyl dipeptide (MDP) respectively, which are produced by both Gram-positive and Gram-negative bacteria $[48,49]$. Direct or indirect ligand recognition by NOD1 and NOD2 recruits receptorinteracting serine/threonine-protein kinase 2 (RIPK2) to induce NF-KB signaling [50]. The activation of NF$\mathrm{KB}$ leads to the synthesis and release of pro-inflammatory mediators, including IL-1 $\beta$, IL-6 and TNF- $\alpha$ [51]. Consequently, the pro-inflammatory cytokines elicit the inflammatory response and result in intestinal injury. In the present study, we firstly investigated the intestinal LPS levels and found that IUGR increased the concentrations of LPS in both jejunum and ileum of weaned piglets. When the intestine is activated by LPS, the mRNA expressions of intestinal TLR4 (TLR4, MyD88, IRAK1 in the jejunum, and TLR4 in the ielum) and NOD signaling-related genes (NOD1, RIPK2 in the jejunum and NOD1, NOD2, RIPK2 in the ileum) and NF-KB p65 were increased in IUGR piglets. The protein expressions of TLR4 and MyD88 in the jejunum and TLR4 in the ileum of IUGR piglets were higher than those of NBW piglets, which were consistent with the results of the related mRNA expressions. IUGR weaned piglets also increased the protein expressions of plкBa and nuclear NF-kB and decreased cytoplasmic pNF-кB in the intestine. Similar results were found in the liver of IUGR rats [52]. There are numerous studies about the mechanism of DHA in alleviating inflammation. However, the research on DHA suppressing intestinal inflammation via TLR4/NODs/NF-KB pathway was limited. Recent study reported that DHA attenuated the inflammation induced by Lupus Nephritis through TLR4 signaling pathway [53]. Jiang et al. [11] demonstrated that DHA derivative DC32 inhibited inflammatory response in osteoarthritic synovium of rats via regulating Nrf2/NF-KB pathway. Study also showed that DHA alleviated autoimmune thyroiditis of rats by inhibiting the CXCR3/PI3K/AKT/NF-KB signaling pathway [54]. In the present study, treatment with DHA effectively decreased the related mRNA expressions of TLR4/NODs/NF-KB pathway, reduced the protein expressions of TLR4, plкBa and nuclear NF-KB and improved cytoplasmic pNF-KB in both jejunum and ileum of IUGR piglets. Therefore, these data indicated that dietary DHA supplementation could alleviate intestinal inflammatory response through TLR4/NODs/NF-KB signaling pathway in IUGR weaned piglets.

It has been reported that TLR4/NODs signaling is also negatively modulated by multiple mechanisms [55]. Numerous regulators of TLR4 and NODs signaling have been identified and characterized.

Researches have shown that Tollip, RP105, and SOCS1 are considered to be the representative negative regulators of TLR4 signaling [56-58] and the typical negative regulators of NOD signaling are ERBB2IP 
and CENTB1 $[59,60]$. In the current study, IUGR decreased the mRNA expressions of Tollip, ERBB2IP, CENTB1 in the jejunum and SOCS1, ERBB2IP, CENTB1 in the ileum of weaned piglets. Diet supplemented with DHA significantly increased the mRNA expressions of jejunal Tollip, ERBB2IP, CENTB1 and ileal SOCS1, ERBB2IP, CENTB1 of IUGR piglets. Similar findings were observed in the intestine of weaned pigs after LPS challenge [14]. The results demonstrated that DHA treatment up-regulated the mRNA expressions of TLR4 and NODs negative regulators in the intestine of IUGR piglets, which were in accordance with the decreased mRNA expressions of intestinal TLR4 and NODs signaling-related genes. Therefore, the inhibitory effects of DHA on TLR4 and NODs signaling might be also attributed to the improvement of related gene expressions of their negative regulators.

\section{Conclusions}

The results obtained in the present study have shown that IUGR piglets exhibited a high risk of intestinal inflammatory response. Dietary supplementation of DHA to IUGR weaned piglets could improve intestinal morphology, regulate the proliferation and apoptosis of enterocytes, and attenuate intestinal inflammatory injury by decreasing the release of pro-inflammatory cytokines via the inhibition of TLR4/NODs/NF-KB signaling pathway. Our findings may be helpful in finding a novel nutritional strategy for IUGR infants to maintain intestinal health in the early life of humans.

\section{Abbreviations}

$\mathrm{Al}$, apoptosis index; CD, crypt depth; CENTB1, centaurin $\beta 1$; DHA, dihydroartemisinin; ERBB2IP, Erbb2 interacting protein; IL-1 $\beta$, interleukin 1 $\beta$; IL-6, interleukin 6; LPS, lipopolysaccharide; IRAK1, IL-1 receptorassociated kinase 1; IUGR, intrauterine growth retardation; MyD88, myeloid differentiation factor 88; NBW, normal birth weight; NLRs, oligomerization domain (NOD)-like receptors; NOD, nucleotide-binding oligomerization domain protein; PCNA, proliferating cell nuclear antigen; plкBa, phosphorylated NF-KB inhibitor a; pNF-kB, phosphorylated nuclear factor KB; PI, proliferation index; RIPK2, receptor-interacting serine/threonine-protein kinase 2; RP105, radioprotective 105; SOCS1, suppressor of cytokine signaling 1; tlkBa, total NF-KB inhibitor a; TLRs, transmembrane toll like receptors; TLR4, toll-like receptor 4; TNF-a, tumor necrosis factor $\alpha$; $\mathrm{tNF}-\mathrm{kB}$, total nuclear factor $\mathrm{kB}$; Tollip, toll-interacting protein; TRAF6, TNF receptor-associated factor 6 ; VCR, villus height to crypt depth ratio; VD, villus width; VH, villus height; VSA, villus surface area.

\section{Declarations}

\section{Acknowledgements}

We would like to thank Wen Xu, Jintian He and Yongwei Zhao for their great contribution and help in pig raising. 


\section{Authors' contributions}

YN, LLZ and TW designed the study. YN, YWZ, JTH, YY, MMS and ZDG performed the study. YN analysed the data and wrote the manuscript. YN and JTH revised the manuscript. TW had had primary responsibility for the final content. All authors read and approved the final manuscript.

\section{Funding}

This research was supported by the National Natural Science Foundation of China (no. 31601948) and the Fundamental Research Funds for the Central Universities (no. KJQN201935).

\section{Availability of data and materials}

All data generated or analysed during this study are included in this published article.

\section{Ethics approval and consent to participate}

All experimental design and procedures were approved by Institutional Animal Care and Use Committee of Nanjing Agricultural University following the requirements of the Regulations for the Administration of Affairs Concerning Experimental Animals of China (NJAU-CAST -2018-14).

\section{Consent for publication}

Not applicable

\section{Competing interests}

The authors declare that they have no competing interests.

\section{Author details}

College of Animal Science and Technology, Nanjing Agricultural University, Nanjing, Jiangsu 210095, China.

\section{References}

1. Wu G, Bazer FW, Wallace JM, Spencer TE. Board-invited review: intrauterine growth retardation: implications for the animal sciences. J Anim Sci. 2006;84:2316-37. 
2. Mcmillen, IC, Robinson JS. Developmental origins of the metabolic syndrome: prediction, plasticity, and programming. Physiol Rev. 2005;85:571-633.

3. Dong L, Zhong X, He JT, Zhang LL, Bai KW, Xu Wen, et al. Supplementation of tributyrin improves the growth and intestinal digestive and barrier functions in intrauterine growth-restricted piglets. Clin Nutr 2016;35:399-407.

4. Fung CM, White JR, Brown AS, Gong HY, Weitkamp JH, Frey MR, et al. Intrauterine growth restriction alters mouse intestinal architecture during development. Plos One. 2016;e0146542.

5. Garite TJ, Clark R, Thorp JA. Intrauterine growth restriction increases morbidity and mortality among premature neonates. Am J Obstet Gynecol. 2004;191:481-7.

6. Longo S, Bollani L, Decembrino L, Comite AD, Angelini M, Stronati M. Short-term and long-term sequelae in intrauterine growth retardation (IUGR). J Matern Fetal Neonatal Med. 2013;26:222-5.

7. Yin J, Xia WW, Zhang Y, Ding GX, Chen LH, Yang GR, et al. Role of dihydroartemisinin in regulating prostaglandin E2 synthesis cascade and inflammation in endothelial cells. Heart Vessels. 2018,33:1411-22.

8. Ho WE, Peh HY, Chan TK, Fred WS, Wong WSF. Artemisinins: pharmacological actions beyond antimalarial. Pharmacol Ther. 2014;142:126-39.

9. Yang DX, Yuan WD, Lv CJ, Li NE, Liu TS, Wang L, et al. Dihydroartemisinin supresses inflammation and fibrosis in bleomycine-induced pulmonary fibrosis in rats. Int J Clin Exp Pathol. 2015;8:1270-81.

10. Li WD, Dong YJ, Tu YY, Tu YY, Lin ZB. Dihydroarteannuin ameliorates lupus symptom of BXSB mice by inhibiting production of TNF-alpha and blocking the signaling pathway NF-kappa B translocation. Int Immunopharmacol. 2006;6:1243-50.

11. Jiang LB, Meng DH, Lee SM, Liu SH, Xu QT, Wang Y, et al. Dihydroartemisinin inhibits catabolism in rat chondrocytes by activating autophagy via inhibition of the NF-KB pathway. Sci Rep. 2016;6:38979.

12. Sanderson IR, Allan WW. TLRs in the Gut I. The role of TLRs/Nods in intestinal development and homeostasis. Am J Physiol Gastrointest Liver Physiol. 2007;292:G6-10.

13. Fang $\mathrm{H}$, Wang PF, Zhou Y, Wang YC, Yang QW. Toll-like receptor 4 signaling in intracerebral hemorrhage-induced inflammation and injury. J Neuroinflammation. 2013;10:27.

14. Wang HB, Liu YL, Shi HF, Wang XY, Zhu HL, Pi DG, et al. Aspartate attenuates intestinal injury and inhibits TLR4 and NODs/NF-KB and p38 signaling in weaned pigs after LPS challenge. Eur J Nutr. 2017;56:1433-43.

15. Fritz JRH, Ferrero RL, Philpott DJ, Girardin SE. Nod-like proteins in immunity, inflammation and disease. Nat Immunol. 2006;7:1250-7.

16. Baldwin AS. Control of oncogenesis and cancer therapy resistance by the transcription factor NFkappa B. J Clin Invest. 2001;107:241-6.

17. Wang T, Huo Y, Shi FX, Xu RJ, Hutz RJ. Effects of intrauterine growth retardation on development of the gastrointestinal tract in neonatal pigs. Biol Neonate. 2005;88:66-72. 
18. D'Inca R, Kloareg M, Guen CGL, Huero-Luron IL. Intrauterine growth restriction modifies the developmental pattern of intestinal structure, transcriptomic profile, and bacterial colonization in neonatal pigs. J Nutr. 2010;140:925-31.

19. Wang JJ, Chen LX, Li DF, Yin YL, Wang XQ, Li P, et al. Intrauterine growth restriction affects the proteomes of the small intestine, liver, and skeletal muscle in newborn pigs. J Nutr. 2008;138:60-6.

20. Scholzen T, Gerdes J. The Ki-67 protein: From the known and the unknown. J Cell Physiol. 2000;182:311-22.

21. Xun WJ, Shi LG, Zhou HL, Hou GY, Cao T, Zhao CP. Effects of curcumin on growth performance, jejunal mucosal membrane integrity, morphology and immune status in weaned piglets challenged with enterotoxigenic Escherichia coli. Int Immunopharmacol. 2015;27:46-52.

22. Zou LJ, Xiong X, Liu HN, Zhou J, Liu YH, Yin YL. Effects of dietary lysozyme levels on growth performance, intestinal morphology, immunity response and microbiota community of growing pigs. J Sci Food Agric. 2019;99:1643-50.

23. Su WP, Zhang H, Ying ZX, Li Y, Zhou L, Wang F, et al. Effects of dietary L-methionine supplementation on intestinal integrity and oxidative status in intrauterine growth-retarded weanling piglets. Eur $\mathrm{J}$ Nutr. 2018;57:2735-45.

24. Zhang LL, Zhang H, Li Y, Wang T. Effects of medium-chain triglycerides on intestinal morphology and energy metabolism of intrauterine growth retarded weanling piglets. Arch Anim Nutr. 2017;71:23145.

25. Che LQ, Hu L, Zhou Q, Peng X, Liu Y, Luo YH, et al. Microbial insight into dietary protein source affects intestinal function of pigs with intrauterine growth retardation. Eur J Nutr. 2020;59:327-44.

26. Li Y, Zhang H, Su WP, Ying ZX, Chen YP, Zhang LL, et al. Effects of dietary Bacillus amyloliquefaciens supplementation on growth performance, intestinal morphology, inflammatory response, and microbiota of intra-uterine growth retarded weanling piglets. J Anim Sci Biotechnol. 2018;9:22-38.

27. Wang YX, Zhang LL, Zhou GL, Liao ZY, Ahmad H, Liu WB, et al. Dietary L-arginine supplementation improves the intestinal development through increasing mucosal Akt and mammalian target of rapamycin signals in intra-uterine growth retarded piglets. Br J Nutr. 2012;108:1371-81.

28. Baserga M, Bertolotto C, Maclennan NK, Hsu JL, Pham T, Laksana GS, et al. Uteroplacental insufficiency decreases small intestine growth and alters apoptotic homeostasis in term intrauterine growth retarded rats. Early Hum Dev. 2004;79:93-105.

29. Cellini C, Xu J, Buchmiller TL. Effect of esophageal ligation on small intestinal development in normal and growth-retarded fetal rabbits. J Pediatr Gastroenterol Nutr. 2006;43:291-8.

30. Porter AG, Janicke RU. Emerging roles of caspase-3 in apoptosis. Cell Death Differ. 1999;6:99-104.

31. Connolly KM, Bogdanffy MS. Evaluation of proliferating cell nuclear antigen (PCNA) as an endogenous marker of cell proliferation in rat liver: a dual-stain comparison with 5-bromo-2'deoxyuridine. J Histochem Cytochem. 1993;41:1-6. 
32. Alqaryyan M, Kilarkaje N, Mouihate A, Al-Bader MD. Dexamethasone-induced intrauterine growth restriction is associated with altered expressions of metastasis tumor antigens and cell cycle control proteins in rat Pplacentas. Reprod Sci. 2016;24:1164-75.

33. Pham TD, Maclennan NK, Chiu CT, Laksana GS, Hsu JL, Lane J. Uteroplacental insufficiency increases apoptosis and alters p53 gene methylation in the full-term IUGR rat kidney. Am J Physiol Regul Integr Comp Physiol. 2003;285:R962-70.

34. Jozawa H, Inoue-Yamauchi A, Arimura S, Yamanashi YJ. Loss of C/EBPס enhances apoptosis of intestinal epithelial cells and exacerbates experimental colitis in mice. Genes Cells. 2019;24:619-26.

35. Huang S, Li N, Liu C, Li TT, Wang W, Jiang LL, et al. Characteristics of the gut microbiota colonization, inflammatory profile, and plasma metabolome in intrauterine growth restricted piglets during the first 12 hours after birth. J Microbiol. 2019;57:748-58.

36. Gao YT, Cui MM, Zhong SJ, Feng CY, Nwobodo AK, Chen B, et al. Dihydroartemisinin ameliorates LPS-induced neuroinflammation by inhibiting the PI3K/AKT pathway. Metab Brain Dis. 2020;35:661-72.

37. Al-Sayeqh AF, Loughlin MF, Dillon E, Mellits KH, Connerton IF. Campylobacter jejuni activates NF-KB independently of TLR2, TLR4, Nod1 and Nod2 receptors. Microb Pathog. 2010;49:294-304.

38. Subramanian S, Geng H, Tan XD. Cell death of intestinal epithelial cells in intestinal diseases. Sheng li xue bao : Acta physiologica Sinica. 2020;72:308-24.

39. Palsson-McDermott EM, O'Neill LAJ. Signal transduction by the lipopolysaccharide receptor, Toll-like receptor-4. Immunology. 2004;113:153-62.

40. Rietschel ET, Kirikae T, Schade FU, Ulmer AJ, Holst O, Brade H, et al. The chemical structure of bacterial endotoxin in relation to bioactivity. Immunobiology. 1993;187:169-90.

41. Wesche H, Henzel WJ, Shillinglaw W, Li S, Cao Z. MyD88: an adapter that recruits IRAK to the IL-1 receptor complex. Immunity. 1997;7:837-47.

42. Cao Z, Xiong J, Takeuchi M, Kurama T, Goeddel DV. TRAF6 is a signal transducer for interleukin-1. Nature. 1996;383:443-6.

43. Muzio M, Natoli G, Saccani S, Levrero M, Mantovani A. The human toll signaling pathway: divergence of nuclear necrosis factor receptor-associated Factor 6 (TRAF6). J Exp Med. 1998;187:2097-101.

44. Didonato JA, Hayakawa M, Rothwarf DM, Zandi E, Karin M. A cytokine-responsive IKB kinase that activates the transcription factor NF-KB. Nature. 1997;388:548-54.

45. Stancovski I, Baltimore D. NF-kappaB activation: the I kappaB kinase revealed? Cell. 1997;91:299302.

46. Scheidereit C. Signal transduction. Docking IkappaB kinases. Nature. 1998;395:225-6.

47. Rothwarf DM, Karin M. The NF-KB activation pathway: a paradigm in information transfer from membrane to nucleus. Sci STKE. 1999;1999:RE1. 
48. Chamaillard M, Hashimoto M, Horie Y, Masumoto J, Qiu S, Saab L, et al. An essential role for NOD1 in host recognition of bacterial peptidoglycan containing diaminopimelic acid. Nat Immunol. 2003;4:702-7.

49. Girardin SE, Boneca IG, Viala J, Chamaillard M, Labigne A, Thomas G, et al. Nod2 is a general sensor of peptidoglycan through muramyl dipeptide (MDP) detection. J Biol Chem. 2003; 278:8869-72.

50. Kanneganti TD, Lamkanfi M, Nunez G. Intracellular NOD-like receptors in host defense and disease. Immunity. 2007;27:549-59.

51. Lawrence T. The nuclear factor NF-kB pathway in inflammation. Cold Spring Harb Perspect Biol. 2009;1:a001651.

52. He JT, Niu Y, Wang F, Wang C, Cui T, Bai KW, et al. Dietary curcumin supplementation attenuates inflammation, hepatic injury and oxidative damage in a rat model of intra-uterine growth retardation. Br J Nutr. 2018;120:537-48.

53. Diao L, Tao J, Wang YQ, Hu Y. Co-delivery of dihydroartemisinin and HMGB1 siRNA by TAT-modified cationic liposomes through the TLR4 signaling pathway for treatment of lupus nephritis. Int $\mathrm{J}$ Nanomed. 2019;14:8627-45.

54. Li YN, Fan ML, Liu HQ, Ma B, Dai WL, Yu BY, et al. Dihydroartemisinin derivative DC32 inhibits inflammatory response in osteoarthritic synovium through regulating Nrf2/NF-KB pathway. Int Immunopharmacol. 2019;74:105701.

55. Wang HB, Liu YL, Shi HF, Wang XY, Zhu HL, Pi DG, et al. Aspartate attenuates intestinal injury and inhibits TLR4 and NODs/NF-KB and p38 signaling in weaned pigs after LPS challenge. Eur J Nutr. 2017;56:1433-43.

56. Divanovic S, Trompette A, Atabani SF, Madan R, Golenbock DT, Visintin A, et al. Negative Regulation of TLR4 Signaling by RP105. Nat Immunol. 2005;6:571-8.

57. Humbert-Claude M, Duc D, Dwir D, Thieren L, Tobel JSV, Begka C, et al. Tollip, an early regulator of the acute inflammatory response in the substantia nigra. J Neuroinflammation. 2016;13:303.

58. Kinjyo I, Hanada T, Inagaki-Ohara K, Mori H, Aki D, Ohishi M, et al. SOCS1/JAB is a negative regulator of LPS-induced macrophage activation. Immunity. 2002;17:583-91.

59. McDonald C, Chen FF, Ollendorff V, Ogura Y, Marchetto S, Lecine P, et al. A Role for Erbin in the Regulation of Nod2-dependent NF-kB Signaling. J Biol Chem. 2005;280:40301-9.

60. Günthner R, Kumar VRS, Lorenz G, Anders HJ, Lech M. Pattern-recognition receptor signaling regulator mRNA expression in humans and mice, and in transient inflammation or progressive fibrosis. Int J Mol Sci. 2013;14:18124-7.

\section{Figures}




\section{NBW-CON}

\section{IUGR-CON}

IUGR-DHA

\section{Jejunum}

Ileum
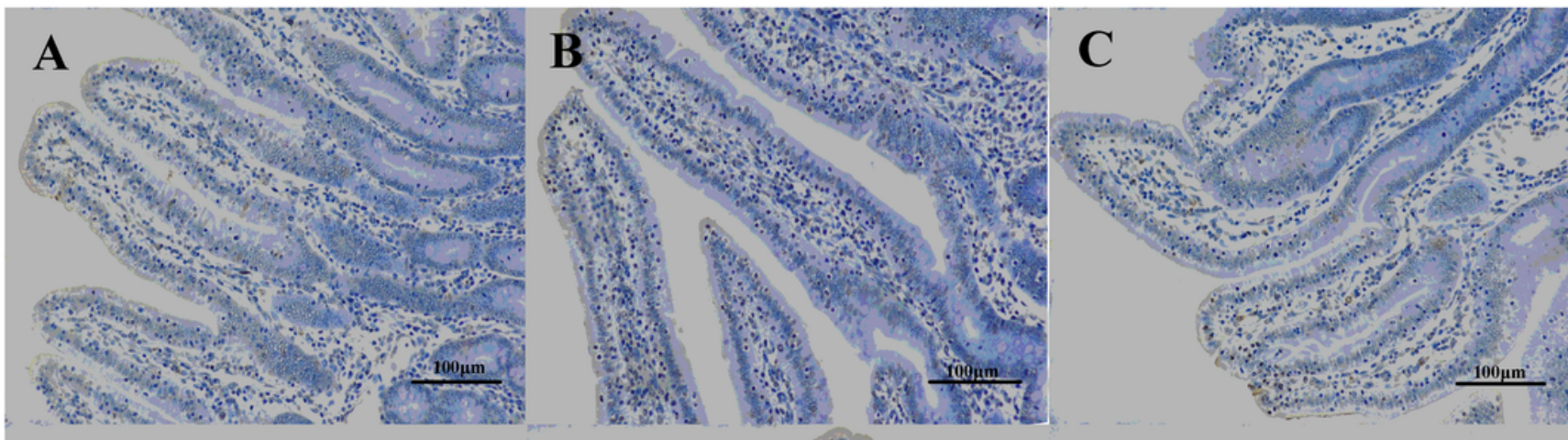

D

E

F

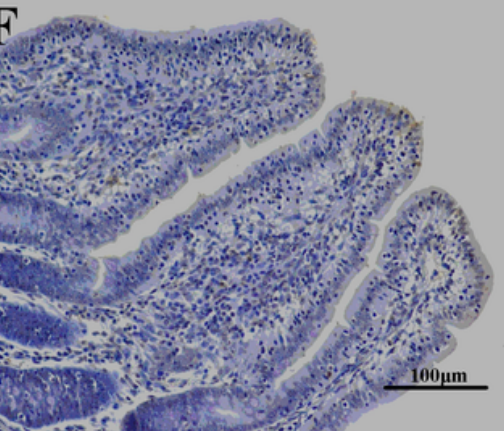

\section{Figure 1}

Representative micrographs of TUNEL staining carried out on paraformaldehyde-fixed sections from the jejunum [(A-C), $200 \times$ magnification] and ileum [(D-F), $200 \times$ magnification] of weaned piglets. The apoptotic cells were stained yellow or brown-yellow. NBW-CON group, normal body weight weaned piglets fed with basal diet; IUGR-CON group, intrauterine growth retardation weaned piglets fed with basal diet; IUGR-DHA group, intrauterine growth retardation weaned piglets fed with $80 \mathrm{mg} / \mathrm{kg}$ dihydroartemisinin. 
NBW-CON

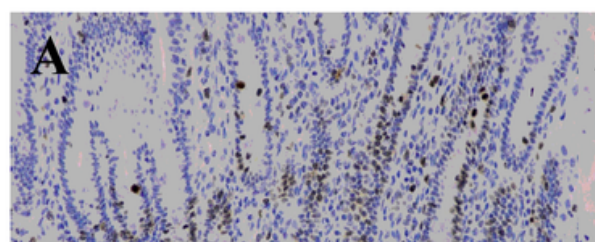

IUGR-CON

IUGR-DHA

\section{Jejunum}

Ileum

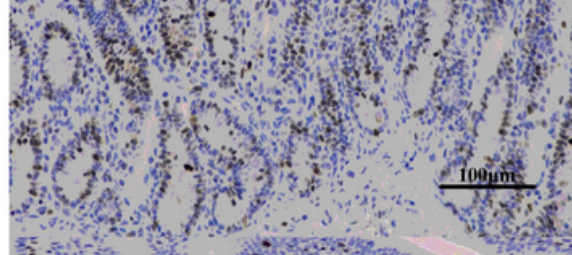

B

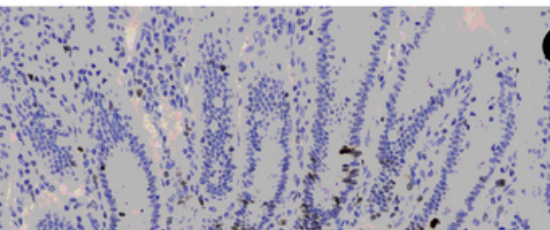

C
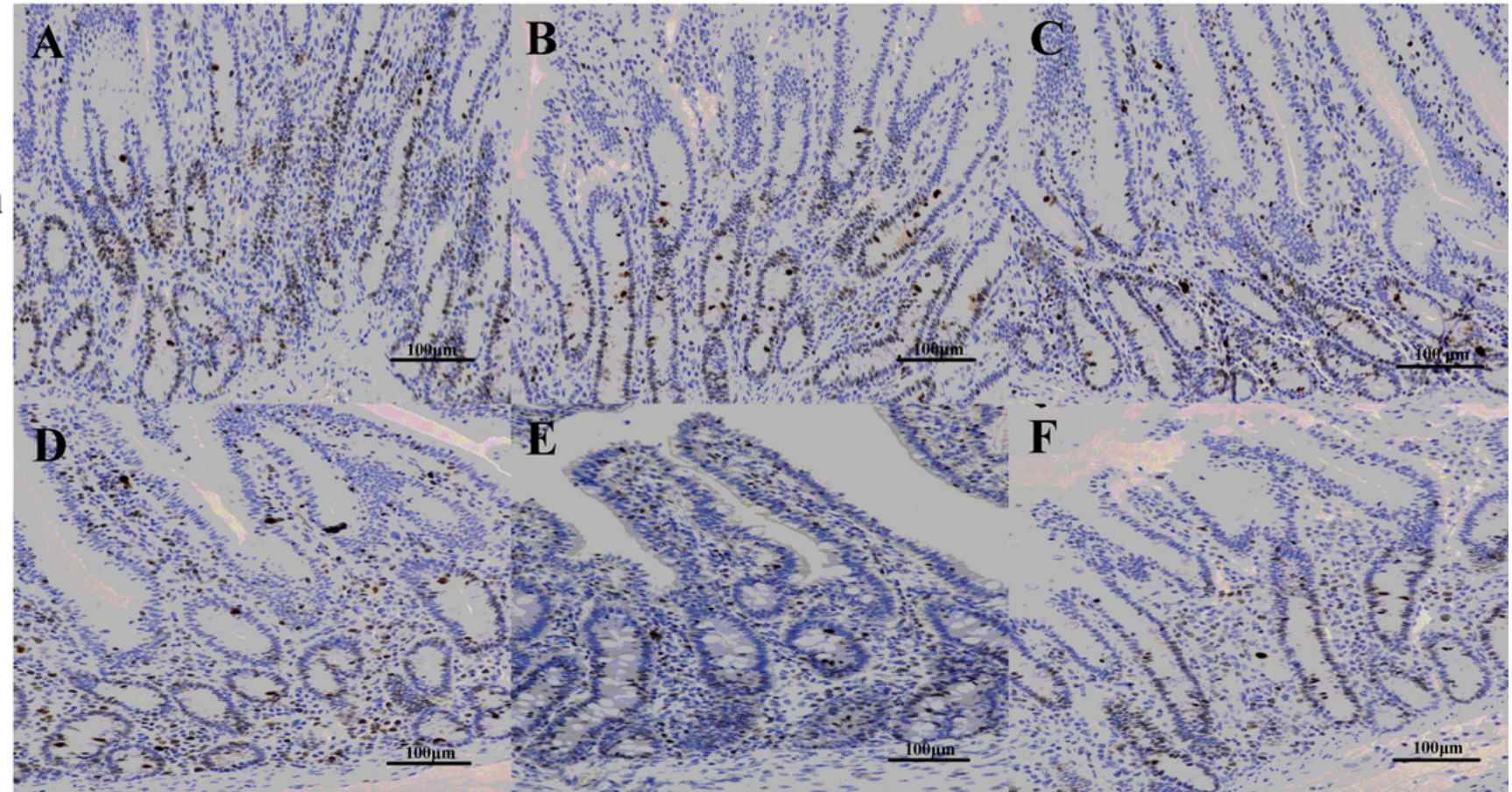


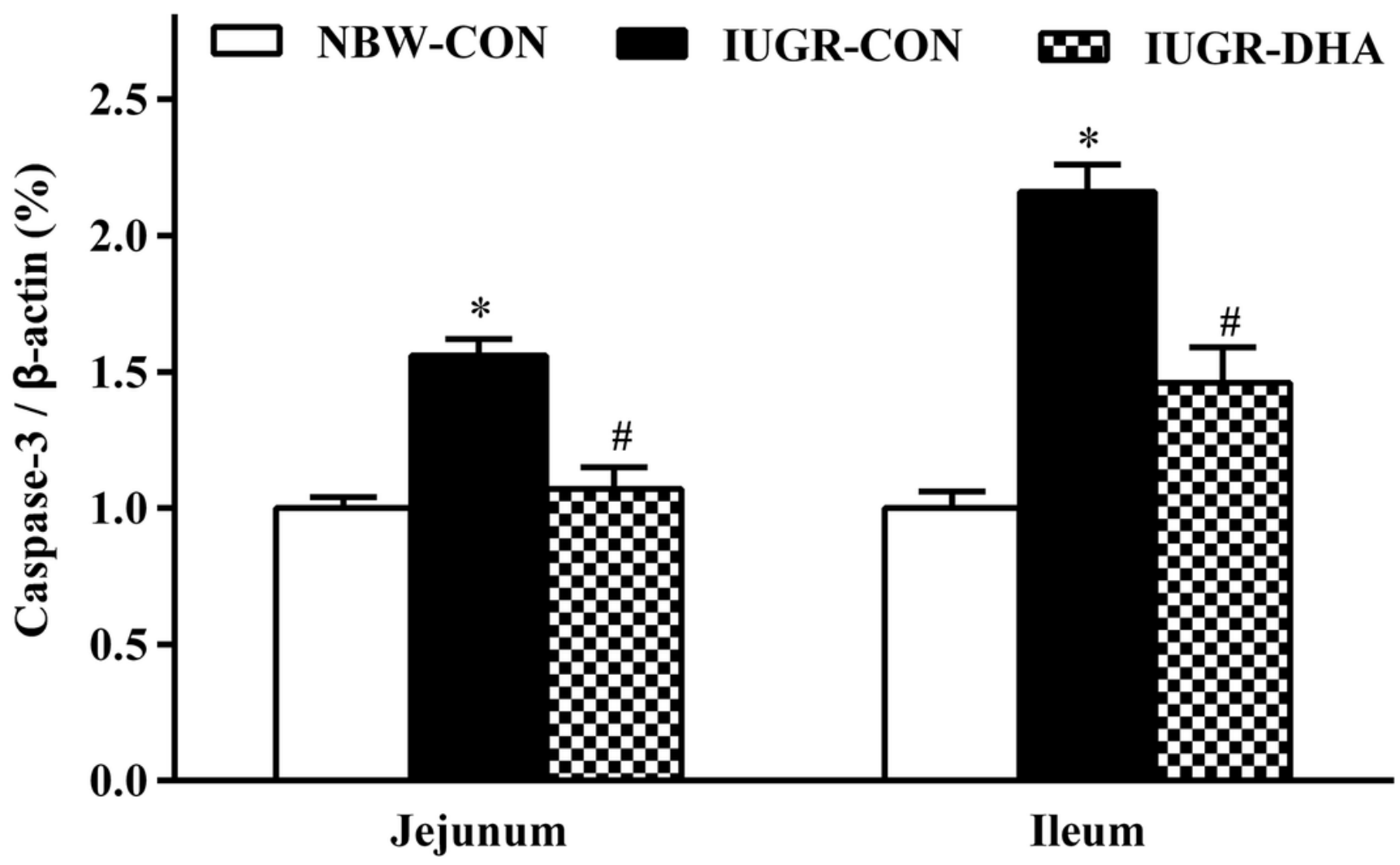

Figure 3

Effect of dietary dihydroartemisinin supplementation on the protein expression of caspase- 3 in the jejunum and ileum of weaned piglets with intrauterine growth retardation. The bands were the representative Western blot images of caspase-3 (32 kDa) and $\beta$-actin (45 kDa). NBW-CON group, normal body weight weaned piglets fed with basal diet; IUGR-CON group, intrauterine growth retardation weaned piglets fed with basal diet; IUGR-DHA group, intrauterine growth retardation weaned piglets fed with 80 $\mathrm{mg} / \mathrm{kg}$ dihydroartemisinin. Data were presented as mean \pm SEM $(\mathrm{n}=8)$. *A significant difference $(P<$ $0.05)$ was observed when compared with NBW-CON group; \#A significant difference $(P<0.05)$ was observed when compared with IUGR-CON group. 


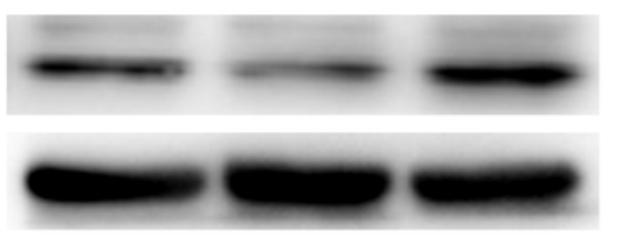

PCNA

$\beta$-actin

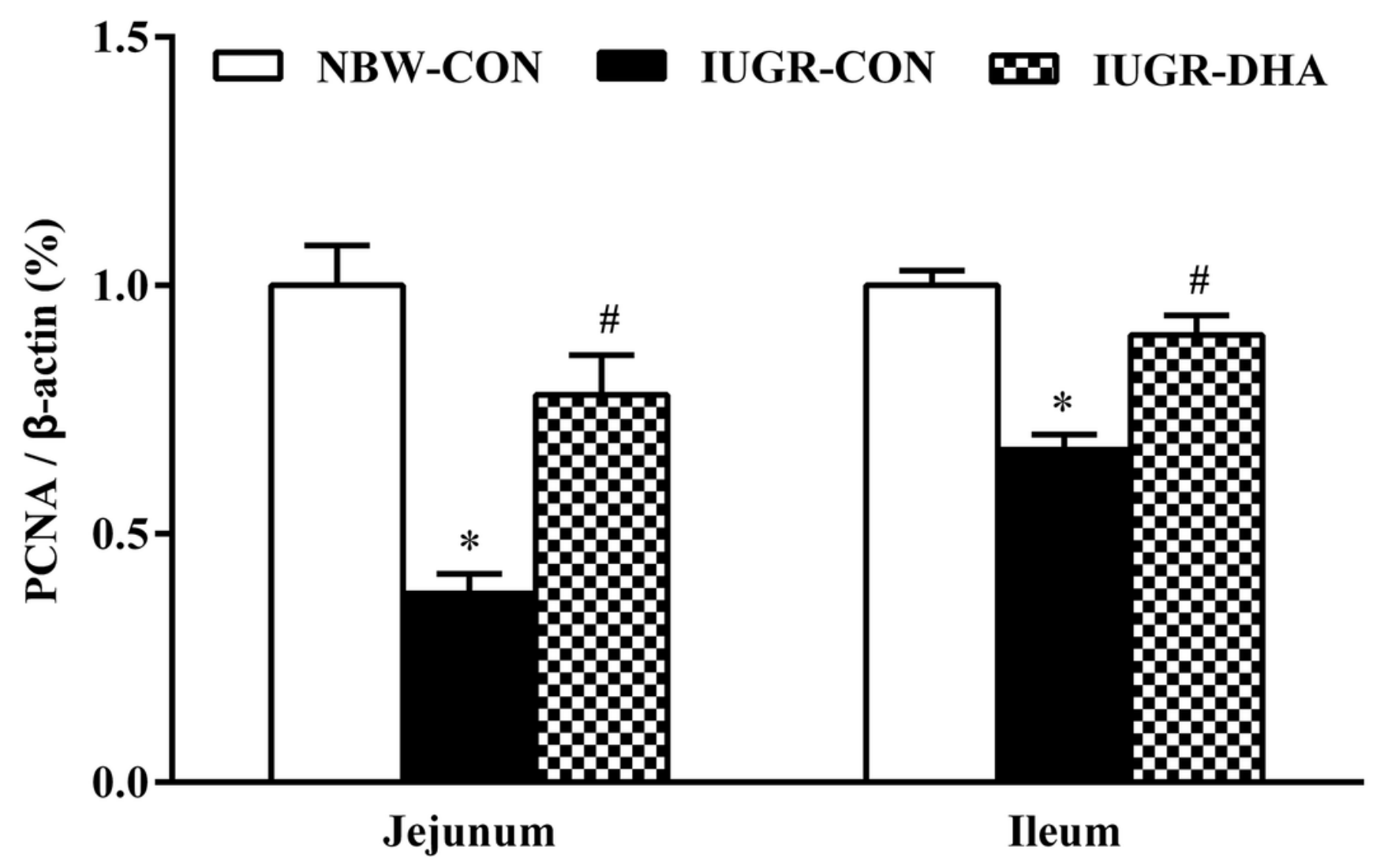

Figure 4

Effect of dietary dihydroartemisinin supplementation on the protein expression of PCNA in the jejunum and ileum of weaned piglets with intrauterine growth retardation. The bands were the representative Western blot images of PCNA (29 kDa) and $\beta$-actin ( $45 \mathrm{kDa}$ ). NBW-CON group, normal body weight weaned piglets fed with basal diet; IUGR-CON group, intrauterine growth retardation weaned piglets fed with basal diet; IUGR-DHA group, intrauterine growth retardation weaned piglets fed with $80 \mathrm{mg} / \mathrm{kg}$ dihydroartemisinin. Data were presented as mean \pm SEM $(n=8)$. *A significant difference $(P<0.05)$ was observed when compared with NBW-CON group; \#A significant difference $(P<0.05)$ was observed when compared with IUGR-CON group. PCNA, proliferating cell nuclear antigen. 


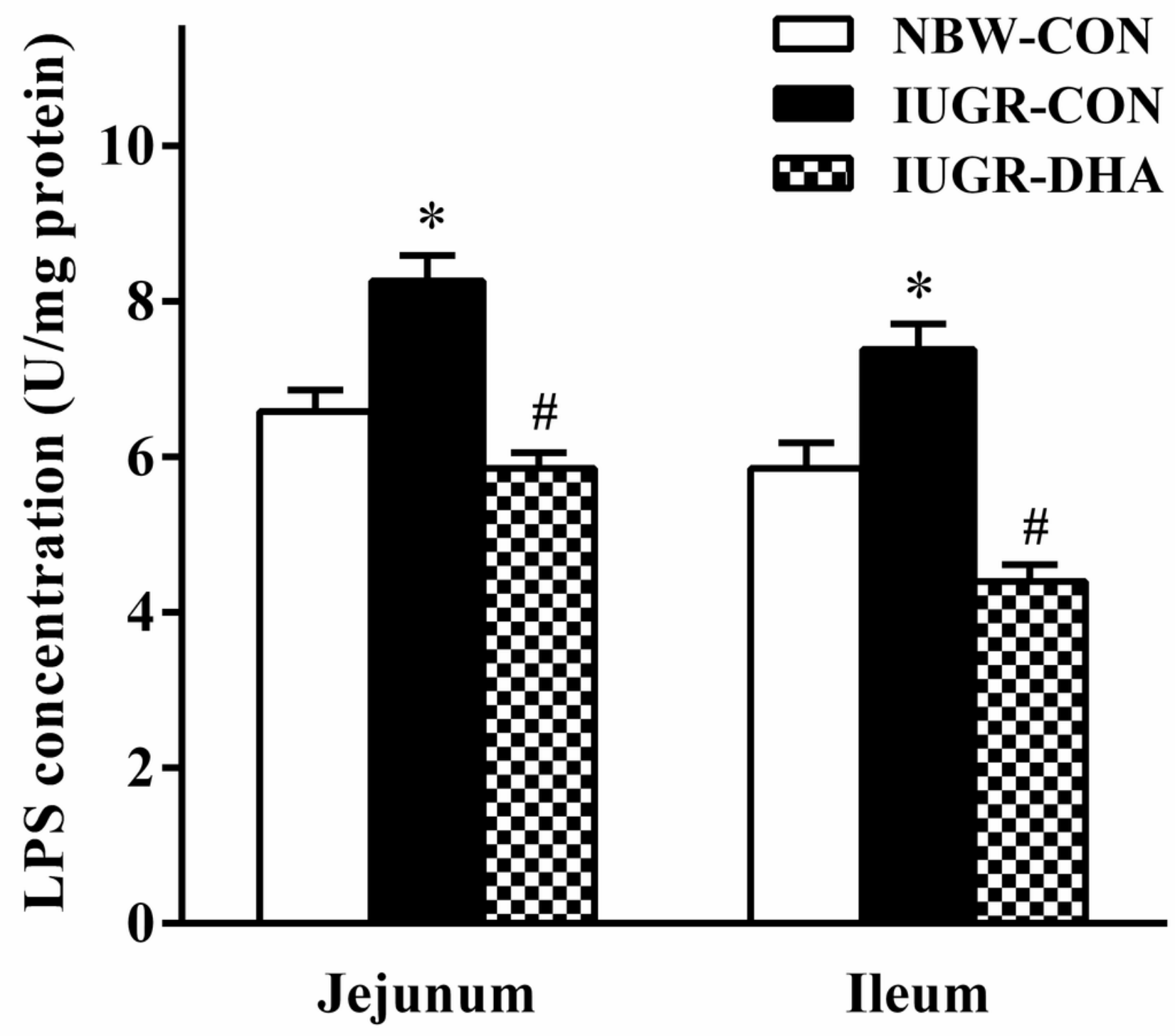

Figure 5

Effect of dietary dihydroartemisinin supplementation on intestinal concentrations of lipopolysaccharide in weaned piglets with intrauterine growth retardation. NBW-CON group, normal body weight weaned piglets fed with basal diet; IUGR-CON group, intrauterine growth retardation weaned piglets fed with basal diet; IUGR-DHA group, intrauterine growth retardation weaned piglets fed with $80 \mathrm{mg} / \mathrm{kg}$ dihydroartemisinin. Data were presented as mean \pm SEM $(n=8)$. *A significant difference $(P<0.05)$ was observed when compared with NBW-CON group; \#A significant difference $(P<0.05)$ was observed when compared with IUGR-CON group. LPS, lipopolysaccharide. 
A

$=-$ TLR4

$\longrightarrow$ Na, K-ATPase

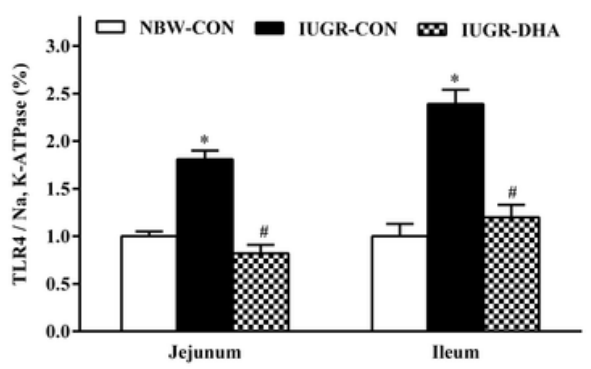

D
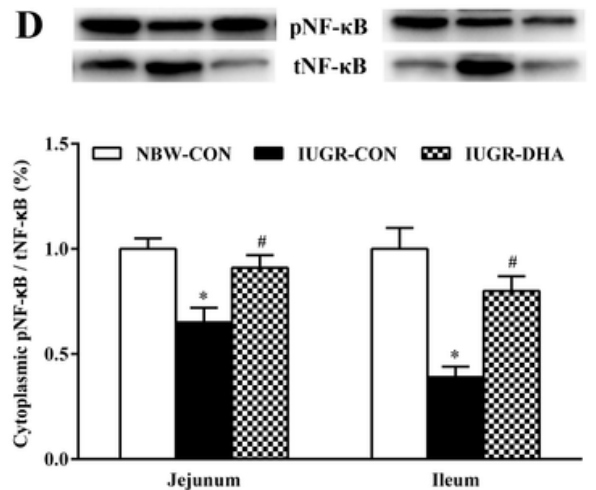

B

MyD88

$\beta$-actin

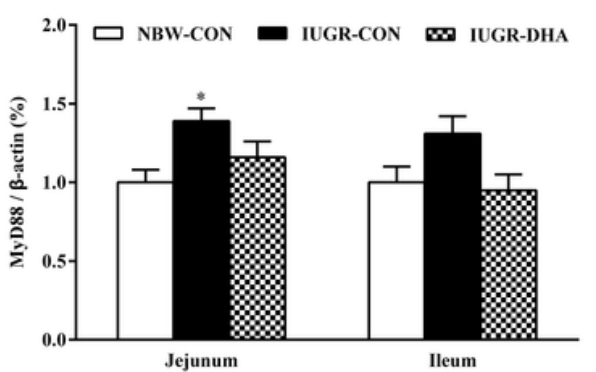

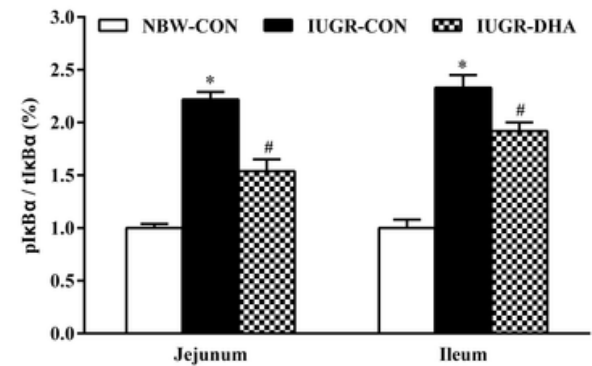

C

pIкBa tIкB $\alpha$

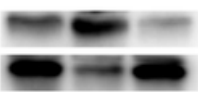

Figure 6

Effect of dietary dihydroartemisinin supplementation on the protein expressions of TLR4 in the membrane (A), MyD88 in the cytoplasm (B), plkBa in the cytoplasm (C), pNF-kB in the cytoplasm (D) and pNF-KB in the nucleus (E) of intestine in weaned piglets with intrauterine growth retardation. The bands were the representative Western blot images of TLR4 (96 kDa), MyD88 (33 kDa), plkBa (39 kDa), tlkBa (40 kDa), tNF-kB (65 kDa), pNF-kB (65 kDa), $\beta$-actin (45 kDa), Na, K-ATPase (100 kDa). NBW-CON group, normal body weight weaned piglets fed with basal diet; IUGR-CON group, intrauterine growth retardation weaned piglets fed with basal diet; IUGR-DHA group, intrauterine growth retardation weaned piglets fed with $80 \mathrm{mg} / \mathrm{kg}$ dihydroartemisinin. Data were presented as mean \pm SEM $(n=8)$. ${ }^{*} A$ significant difference $(P<0.05)$ was observed when compared with NBW-CON group; \#A significant difference $(P<0.05)$ was observed when compared with IUGR-CON group. TLR4, toll-like receptors 4; MyD88, myeloid differentiation factor 88; tlkBa, total NF-kB inhibitor a; plkBa, phosphorylated NF-kB inhibitor a; tNF-kB, total nuclear factor $\mathrm{kB}$; pNF-кB, phosphorylated nuclear factor $\mathrm{kB}$. 